Final

\title{
INCREASED OIL PRODUCTION AND RESERVES UTILIZING SECONDARY/TERTIARY RECOVERY TECHNIQUES ON SMALL RESERVOIRS IN THE PARADOX BASIN, UTAH
}

(Contract No. DE-FC22-95BC14988)

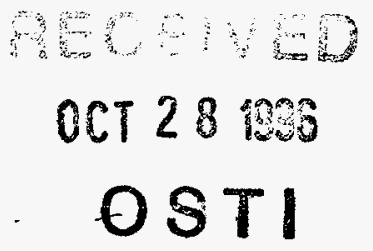

\section{TECHNICAL PROGRESS REPORT}

\author{
Submitted by \\ Utah Geological Survey \\ Salt Lake City, Utah 84114 \\ August 1996

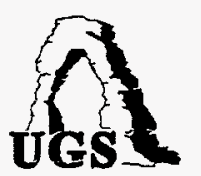

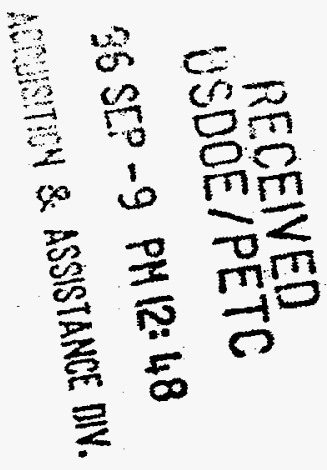

Contract Date: February 9, 1995

Anticipated Completion Date: February 8, 2000

Government Award (fiscal year): $\$ 448,800$

Program Manager: Thomas C. Chidsey, Jr.

Principal Investigator: M. Lee Allison

Contracting Officer's Representative

Rhonda P. Lindsey

U.S. Department of Energy

Bartlesville Project Office

P.O. Box 1398

Bartlesville, OK 74005

Reporting Period: April 1 - June 30, 1996

US/DOE Patent Clearance is not required prior to the publication of this document. 


\section{DISCLAIMER}

Portions of this document may be illegible in electronic image products. Images are produced from the best available original document. 


\section{DISCLAIMER}

This report was prepared as an account of work sponsored by an agency of the United States Government. Neither the United States Government nor any agency thereof, nor any of their employees, makes any wartanty, express or implied, or assumes any legal liability or responsibility for the accuracy, completeness, or usefulness of any information, apparatus, product, or process disclosed, or represents that its use would not infringe privately owned rights. Reference herein to any specific commercial product, process, or service by trade name, trademark, manufacturer, or otherwise does not necessarily constitute or imply its endorsement, recommendation, or favoring by the United States Government or any agency thereof. The views and opinions of authors expressed herein do not necessarily state or reflect those of the United States Government or any agency thereof. 


\section{INCREASED OIL PRODUCTION AND RESERVES UTILIZING SECONDARY/TERTIARY RECOVERY TECHNIQUES ON SMALL RESERVOIRS IN THE PARADOX BASIN, UTAH}

Contract No. DE-FC22-95BC14988

Utah Geological Survey (UGS), Salt Lake City, Utah 84114-6100

Submitted: August 1996

Award Date: February 9, 1995

Anticipated Completion Date: February 8, 2000

Government Award for Current Fiscal Year: $\$ 448,800$

Principal Investigator: M. Lee Allison, UGS

Program Manager: Thomas C. Chidsey, Jr., UGS

Contracting Officer's Representative: Rhonda P. Lindsey, Bartlesville Project Office

Reporting Period: April 1 - June 30, 1996

\section{Objectives}

The primary objective of this project is to enhance domestic petroleum production by demonstration and technology transfer of an advanced oil recovery technology in the Paradox basin, southeastern Utah. If this project can demonstrate technical and economic feasibility, the technique can be applied to approximately 100 additional small fields in the Paradox basin alone, and result in increased recovery of 150 to 200 million barrels of oil. This project is designed to characterize five shallow-shelf carbonate reservoirs in the Pennsylvanian (Desmoinesian) Paradox Formation and choose the best candidate for a pilot demonstration project for either a waterflood or carbon dioxide$\left(\mathrm{CO}_{2}-\right)$ flood project. The field demonstration, monitoring of field performance, and associated validation activities will take place in the Paradox basin within the Navajo Nation. The results of this project will be transferred to industry and other researchers through a petroleum extension service, creation of digital databases for distribution, technical workshops and seminars, field trips, technical presentations at national and regional professional meetings, and publication in newsletters and various technical or trade journals. 


\section{Summary of Technical Progress}

Four activities continued this quarter as part of the geological and reservoir characterization of productive carbonate buildups in the Paradox basin: (1) reservoir characterization of carbonate buildups, (2) reservoir engineering analysis of Anasazi field, (3) geostatistical modeling, and (4) technology transfer.

\section{Reservoir Characterization of Carbonate Buildups}

\section{Carbonate Buildup Process}

Productive carbonate buildups are located in the shallow-shelf and shelf-margin areas. These buildups can be divided into three types: (1) phylloid algal, (2) coralline algal, and (3) bryozoan. ${ }^{1}$ The controls on the development of each buildup type were water depth, prevailing wave energy, and paleostructural position. Mapping of seismic anomalies and reservoir thicknesses indicates that carbonate phylloid-algal buildups or mounds were doughnut or horseshoe shaped or a composite of the two shapes. Many of the phylloid algal buildups were large enough to enclose interior lagoons.

The principal buildup process, phylloid-algal growth, occurred during high stands of sea level (Fig. 1A). ${ }^{2}$ Phylloid-algal mounds generally developed on the platform-interior carbonate muds and sands. The mound substrate of platform-interior carbonates is referred to as the platform interval. Calcified phylloid-algal plates sheltered abundant primary "vugs," with mounds of phylloid algae building upward within the available accommodation space. As mounds grew, detrital skeletal material was shed and deposited as dipping beds along the exterior flanks and interior lagoons. The floors of the interior lagoons consisted of muddy marine limestone with fossils. Early marine cementation commonly occurred along mound walls facing open-marine environments. Bryozoandominated buildups developed in deeper water along the flanks of the phylloid-algal mounds. Coralline-algal buildups developed in association with marine-cemented walls and detrital-fan complexes. These skeletal bafflestone and cementstone portions of the buildups are referred to as mound-core intervals and are easily identified in core.

During low stands of sea level, these buildups experienced considerable porosity modification (Fig. 1B). Leached cavities, vugs, and seepage-reflux dolomites developed in the mound core and flank sediments. Evaporitic dolomites and anhydrite filled the interior lagoons. Islands consisting of high-depositional energy calcarenites and low-depositional energy stromatolites, as well as troughs representing tidal channels formed on the tops of buildups during times of subaerial exposure (Fig. 1B and C). These portions of the buildups are referred to as supramound intervals.

\section{Trapping Mechanism and Reservoir Heterogeneity}

Hydrocarbons are stratigraphically trapped in porous and permeable lithotypes within the mound-core and supra-mound intervals of the Desert Creek carbonate buildups. These intervals are effectively sealed by impermeable platform intervals at the base, marine muds on the flanks, and a 20-ft-thick layer of anhydrite, usually at the top of the Desert Creek zone. Primary oil recovery is about $40 \%$ in mound-core intervals but $15 \%$ or less in the supra-mound intervals. In these traps, 


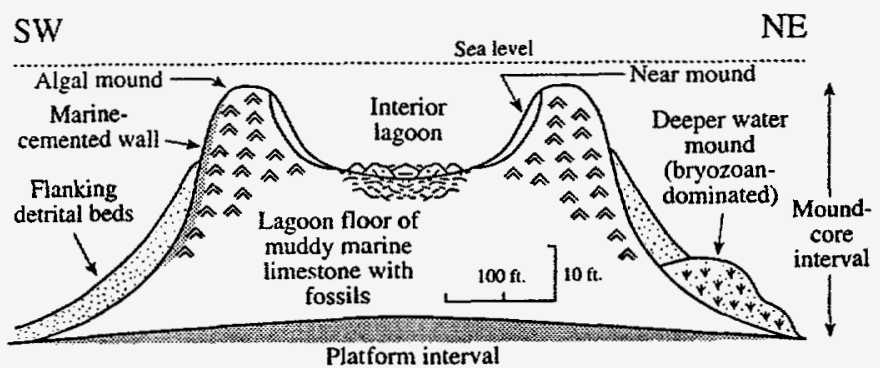

(A)

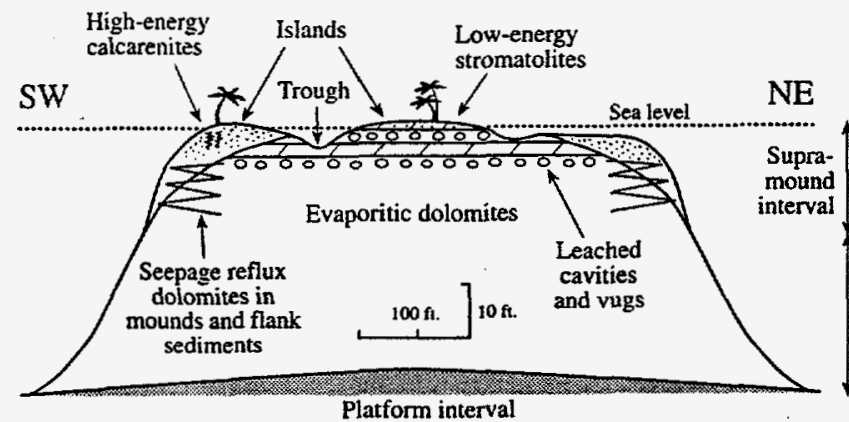

(B)

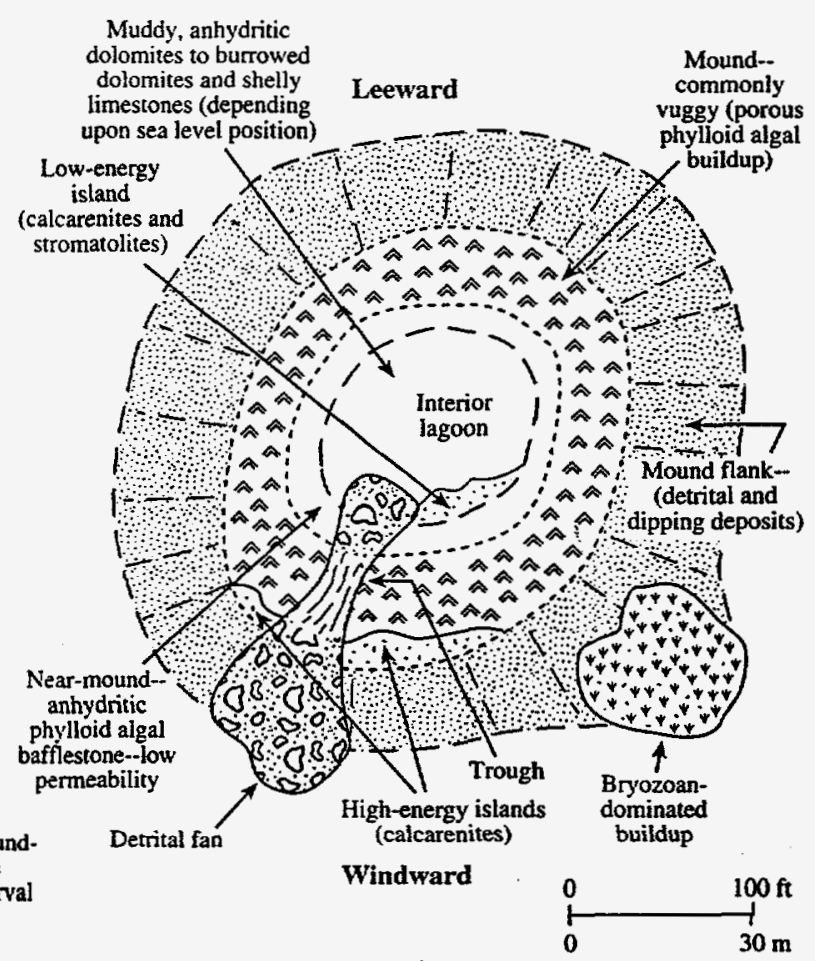

(C)

Figure 1. Detailed environmental setting of Desert Creek algal buildup features surrounding the Greater Aneth field. (A) Cross section during high stands of sea level when the mound was actively growing. (B) Cross section during low stands of sea level when the mound experienced porosity modification, erosion of the mound margins, evaporite dolomites filled in the lagoon, and troughs (tidal channels) and islands developed on the top. (C) Map view of idealized algal buildup. 
determining the nature, location, and extent of reservoir heterogeneity is the key to increasing oil recovery.

Three factors create reservoir heterogeneity within productive mound-core and supra-mound intervals: (1) variations in lithotypes, (2) diagenesis, and (3) mound relief and flooding surfaces. These factors extent and how they are combined affect the degree to which they create barriers to fluid flow.

Lithotypes. Ten distinct lithotypes, each of which exhibits a characteristic set of reservoir properties, have been identified from conventional core in the mound-core and supra-mound intervals. They include: tight mudstones, packstones, wackestones, and marine-cemented grainstones (also present on the buildup flanks of both intervals); similar carbonate fabrics (mudstones, packstones, wackestones, and grainstones) exhibiting enhanced porosity resulting from dolomitization and/or leaching found in the supra-mound interval (and also scattered throughout the buildup flank areas); and thick, porous, highly permeable phylloid-algal lime bafflestones; and associated mound-flank breccias (slumped and chaotic mixed carbonates) which are almost entirely restricted to the mound-core interval. Geometries and patterns of spatial arrangement of these lithotypes can be inferred from outcrop analogue studies and by comparison with previous work in the nearby Greater Aneth field. $3-7$

The mound-core intervals are the most homogenous part of these buildups and are dominated by bafflestones and a few thin dolomudstones, packstones, and wackestones. The overlying supramound intervals exhibit the greatest heterogeneity with multiple combinations of lithotypes and various lithofacies thicknesses. Overall, the supra-mound intervals have lower permeability but surprisingly higher average porosity than the underlying mound-core intervals.

Diagenesis. The principal types of diagenesis which influence reservoir quality within these buildup fields are cementation, leaching, dolomitization, stylolitization, and anhydrite or bitumen plugging. During early diagenesis, reservoir quality is often modified by leaching (dissolution) of framework grains and mixing-zone dolomitization. Early marine cementation can add rigidity to the buildup complex. Of course, extensive marine cementation results in diminished reservoir quality.

During late (burial) diagenesis, stylolite development is common and dissolution along some stylolites enhances reservoir quality. Extensive burial dolomitization, cementation along stylolites, plugging of pores and pore throats by bitumen (particularly in grainstones) and/or anhydrite are the major causes of reservoir quality reduction in the buildups. Within many mound-core intervals, the upper portions of the algal bafflestones are extensively plugged with anhydrite forming barriers or baffles to fluid flow.

Mound Relief and Flooding Surfaces. The nature of the original surfaces of supra-mound intervals can add to the reservoir heterogeneity of these buildups. For example, multiple troughs formed by tidal currents may contain good quality grainstones. However, these grainstones are typically separated by poor quality lithotypes which were deposited adjacent to the troughs. In addition, these deposits may not be connected to one another in other parts of the buildup surfaces. Thus, what might appear as the same units in core or on geophysical logs from one well to another, may be time equivalent but separate in terms of fluid flow.

Subaerial exposure of the buildups may have produced karst zones (depending on prior mound relief) favorable to reservoir development. Relative sea level rise produced flooding surfaces 
or time lines, usually thin shales, which act as barriers or baffles to fluid flow. As many as eight correlative flooding surfaces have been identified in some buildups. Lithotypes between these surfaces are genetically related in time and space, thus correlation of these sequences must not cross time lines. ${ }^{4}$

\section{Reservoir Engineering Analysis of Anasazi Field}

During this quarter team members performed the following reservoir engineering analysis of Anasazi field within the Navajo Nation, San Juan Co., Utah:

1. Completion of high-pressure mercury injection capillary pressure measurements on end pieces from conventional core samples used for-relative permeability measurements of the supra-mound interval (dolomite) and mound-core interval (limestone) facies.

2. Finalization of geologic model development of the Anasazi reservoir units for use in reservoir simulation studies.

3. Completion of a series of one-dimensional (1-D), $\mathrm{CO}_{2}$-displacement simulations to analyze the $\mathrm{CO}_{2}$-displacement mechanism that could operate in the Paradox basin system of reservoirs.

4. Completion of the initialization of the full field, three-dimensional (3-D) Anasazi reservoir simulation model and the initiation of the history matching phase of the simulation study.

Capillary pressure data generation, using high-pressure mercury injection $(>50,0,00$ pounds per square inch [psi]) was completed on the end pieces of the core samples used to develop relative permeability data for the dolomite and limestone productive facies from the Anasazi reservoir. The tests were conducted to compare reservoir properties of samples used for the relative permeability measurements to previously measured properties on core from the Anasazi No. 5L-3 well. Capillary pressure and pore-size-distribution data of samples from the Anasazi Nos.1 and $6 \mathrm{H}-1$ wells were comparable to similar measurements taken on core samples from the Anasazi No. 5L-1 well. Pore size distribution plots are shown in Fig. 2.

Employing fluid property data (represented via a tuned equation of state) and rock property data, 1-, 2-, and 3-D models were successfully developed to simulate both primary depletion and $\mathrm{CO}_{2}$ displacement processes. Optimum numerical solution procedures were also determined to reduce computer time required for both $1-\mathrm{D}$ and 3-D simulation runs. A series of $1-\mathrm{D}, \mathrm{CO}_{2}$ displacement tests for various reservoir operating pressures were conducted using the original Anasazi reservoir fluid composition. These tests indicated that miscibility would be developed between 2500 and 3000 psi. Three plots (Fig. 3) which show the variation of composition of both liquid and vapor phases as a function of time for a selected cell in the 1-D model, illustrate the development of miscibility ( 3000 pounds per square inch absolute [psia]) or near miscibility (2500 psia). 


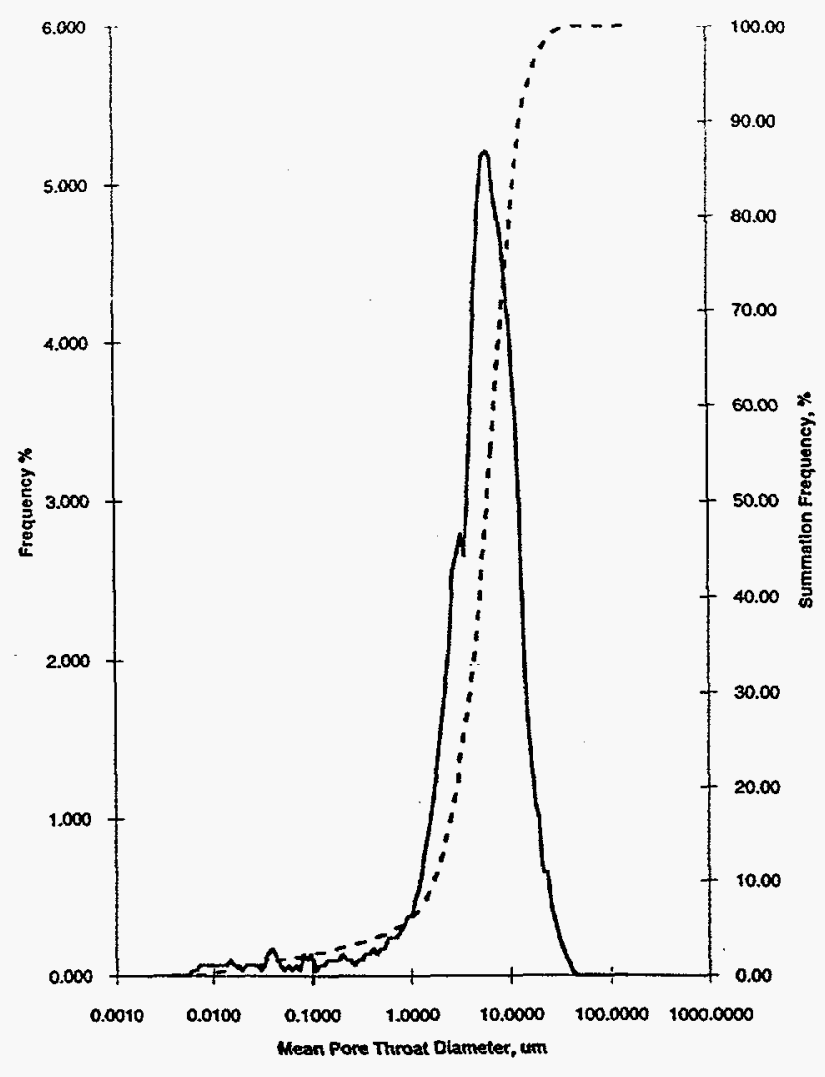

(A)

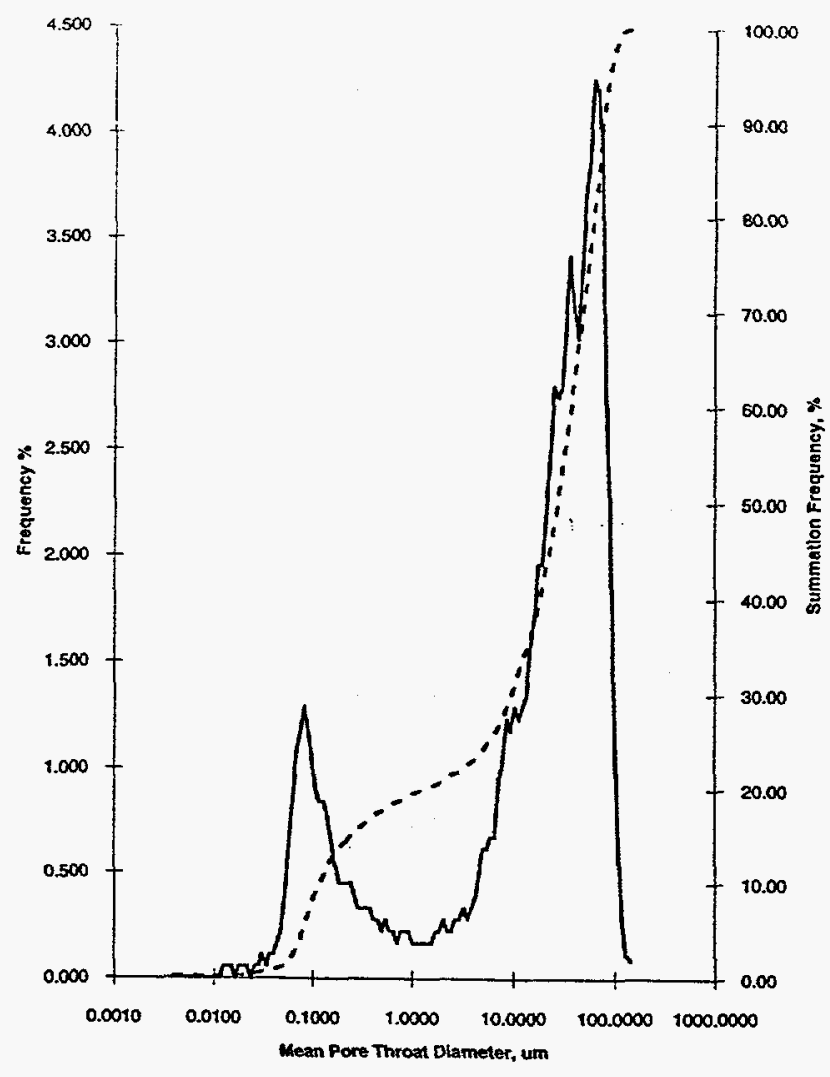

(B)

Figure 2. Pore size distribution plots for Anasazi field, San Juan Co., Utah. (A) Supramound interval (dolomite) facies, Anasazi No. 6 H-1 well. (B) Mound-core interval (limestone) facies, Anasazi No. 1 well. 

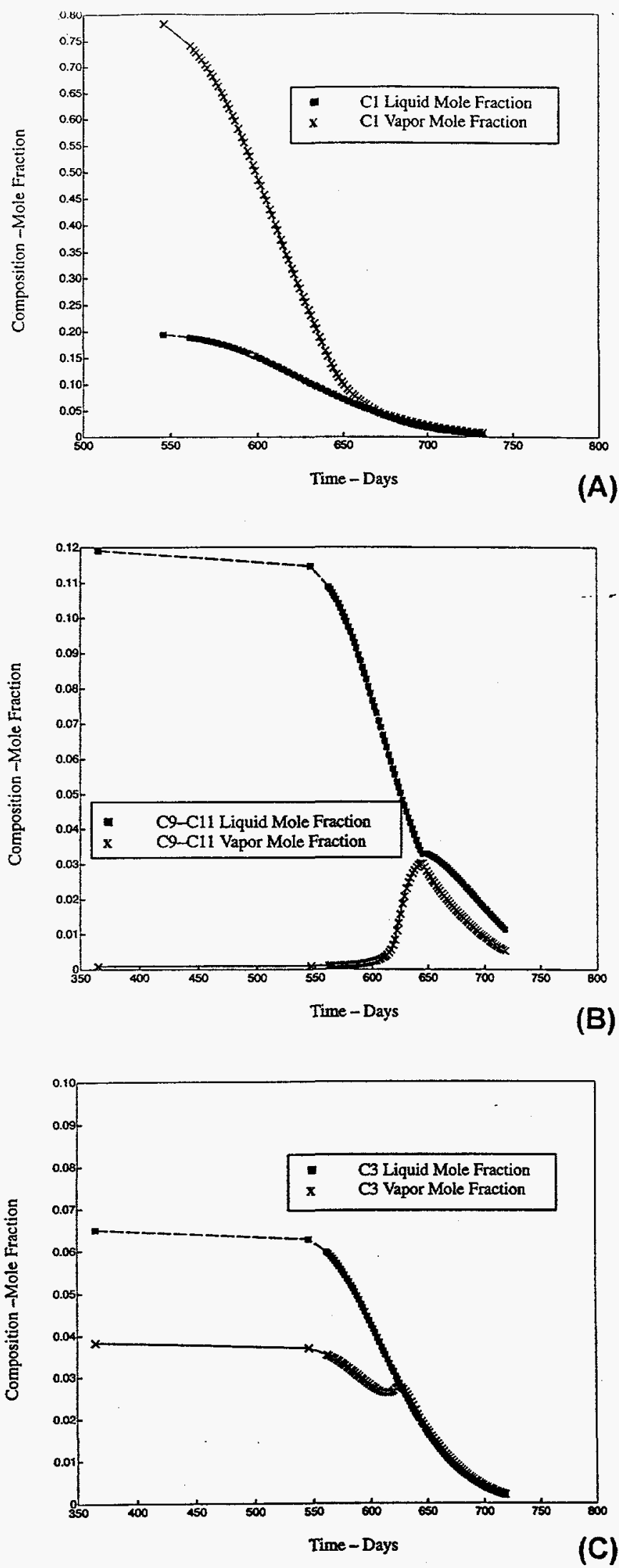

Figure 3. Variation of composition (mole fraction) of both liquid and vapor phases as a function of time (days) for selected cell in the 1-D model. (A) $\mathrm{CO}_{2}$ displacement at 3000 psia; composition versus time for cell 202. (B) $\mathrm{CO}_{2}$ displacement at 2500 psia; composition versus time for cell 217 component $\mathrm{C} 9$ through $\mathrm{C11}$. (C) $\mathrm{CO}_{2}$ displacement at 2500 psia; composition versus time for cell 217 component $C 3$. 
History matching of the primary depletion stage of the Anasazi reservoir using the full field, 3-D simulation model was started. The influence of variations in rock compressibility, variations in total pore volume, and changes in permeability and its distribution are systematically being investigated to calibrate the model to obtain agreement between predicted and observed production and pressure history. Figure 4 illustrates the model grid system as well as the sharply contrasting gas saturation distribution in the main Anasazi carbonate buildup.

\section{Geostatistical Modeling}

An initial set of ten geostatistical, equally probable representations of lithologic and reservoir properties in the Anasazi reservoir complex has been generated. Based on borehole data and production tests from four wells, interpretations of six 2-D seismie sections, well and field production data, and studies of geologically similar outcrop analogues, an extensive array of both hard and soft data constraints was developed and applied throughout the modeling process.

Reservoir model generation followed a five-stage procedure specifically designed for this project:

1. Monte Carlo generation of a 5 million-point, joint-probability distribution function (pdf) of the ten carbonate lithotype volumes identified in the Anasazi reservoir.

2. Using a random sample from this volume distribution, an initial model of reservoir architecture was obtained by stochastic emplacement of the various lithotype bodies within the reservoir volume. The sizes, shapes, orientations, and spatial distributions of these simple geometric bodies were constrained by observed data from wells, outcrops, and field analogues of modern carbonate facies.

3. Porosity values were then randomly assigned to each of these 75,000 individual lithotype blocks, constrained by the porosity pdf's developed for each lithotype from $\log$ and conventional core data. These porosity blocks were stochastically rearranged within the reservoir by simple gridblock exchange, using simulated annealing procedures to fit the vertically averaged reservoir porosity to the constraining porosity map based on the seismic-derived "reservoir quality index" (RQI). A secondary objective function, based on the vertical and lateral spatial covariance exhibited by porosity within the individual lithotypes in the Anasazi wells and in previous studies, also was fit to the model.

4. Horizontal and vertical permeability were estimated from the resulting porosities using randomized transfer functions developed from the Anasazi core data.

5. To accommodate typical computer workstation constraints, the 50-layer geostatistical reservoir models, (Figs. 5 and 6) were rescaled to 15 layers (Figs. 7 and 8). Although most major reservoir features are preserved (for example phylloid-algal limestones [bafflestones] in the mound-core interval [shown as uniformly dark gray bodies in the illustrations] and thin, continuous and porous grainstones of the supra-mound 


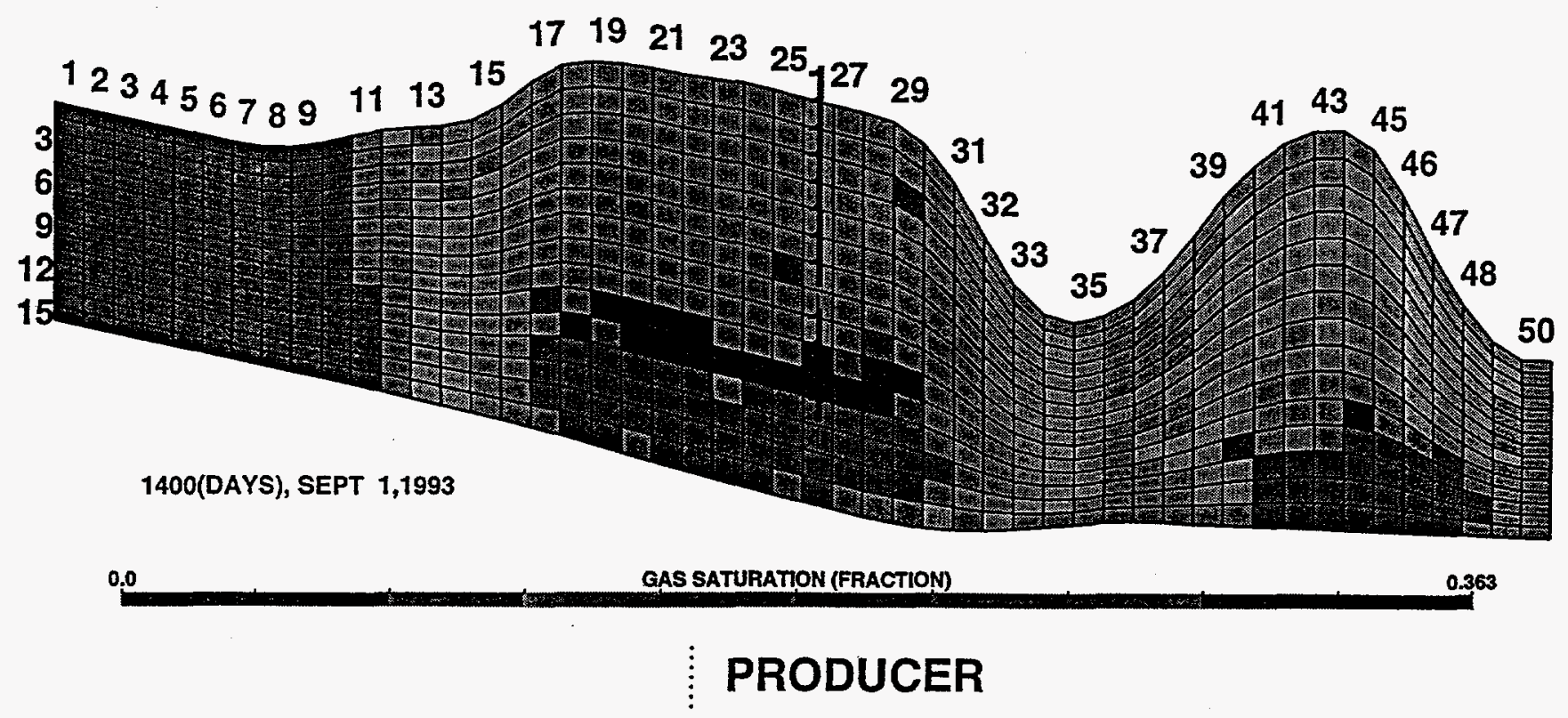

FRONT XZ PLANE FOR $Y=20$

Figure 4. Anasazi field model grid system cross section through the Anasazi No. 1 well illustrating the gas saturation distribution as of September 1996. 


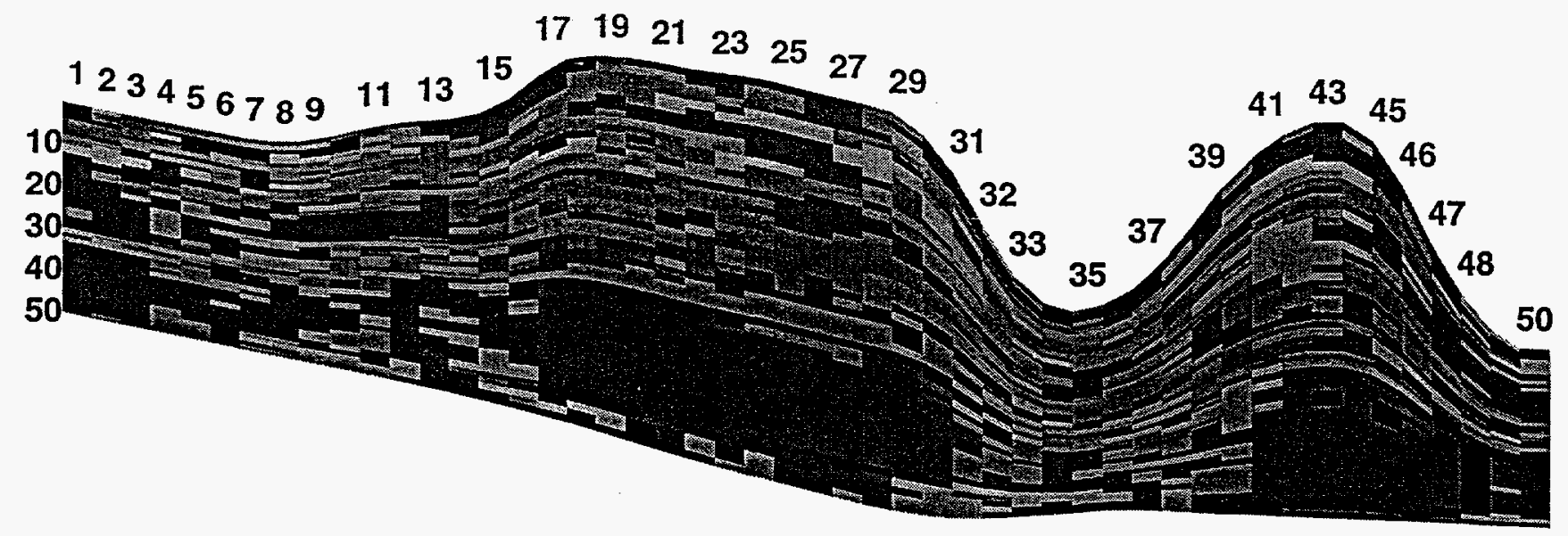

ROCK TYPES - SPATIAL VARIATION

10.0

FRONT XZ PLANE FOR $Y=20$

Figure 5. Cross section, through the Anasazi No. 1 well, of the 50-layer geostatistical Anasazi reservoir simulation model displaying the spatial distribution of lithotypes. Phylloid-algal limestones (bafflestones) in the mound-core interval are shown as uniformly dark gray bodies. Thin, porous grainstones of the supra-mound interval draped across the top of the mound core are shown as light-to-medium gray bodies.

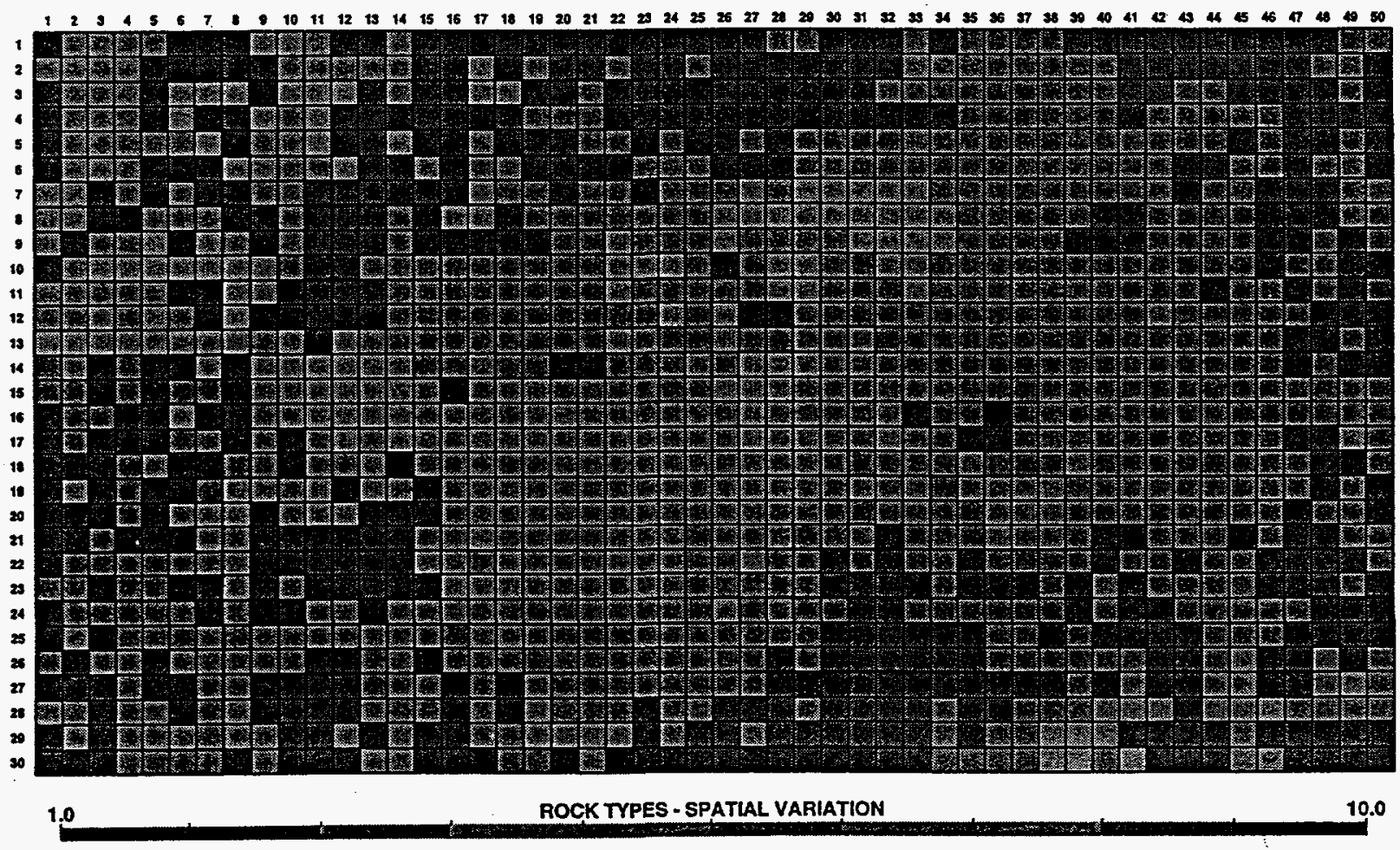

FRONT XY PLANE FOR $Z=30$

Figure 6. Spatial distribution of lithotypes at layer 30 from the 50-layer geostatistical Anasazi reservoir simulation model. 


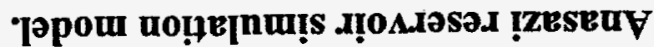

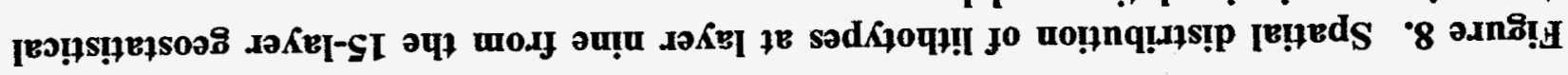

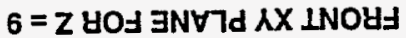

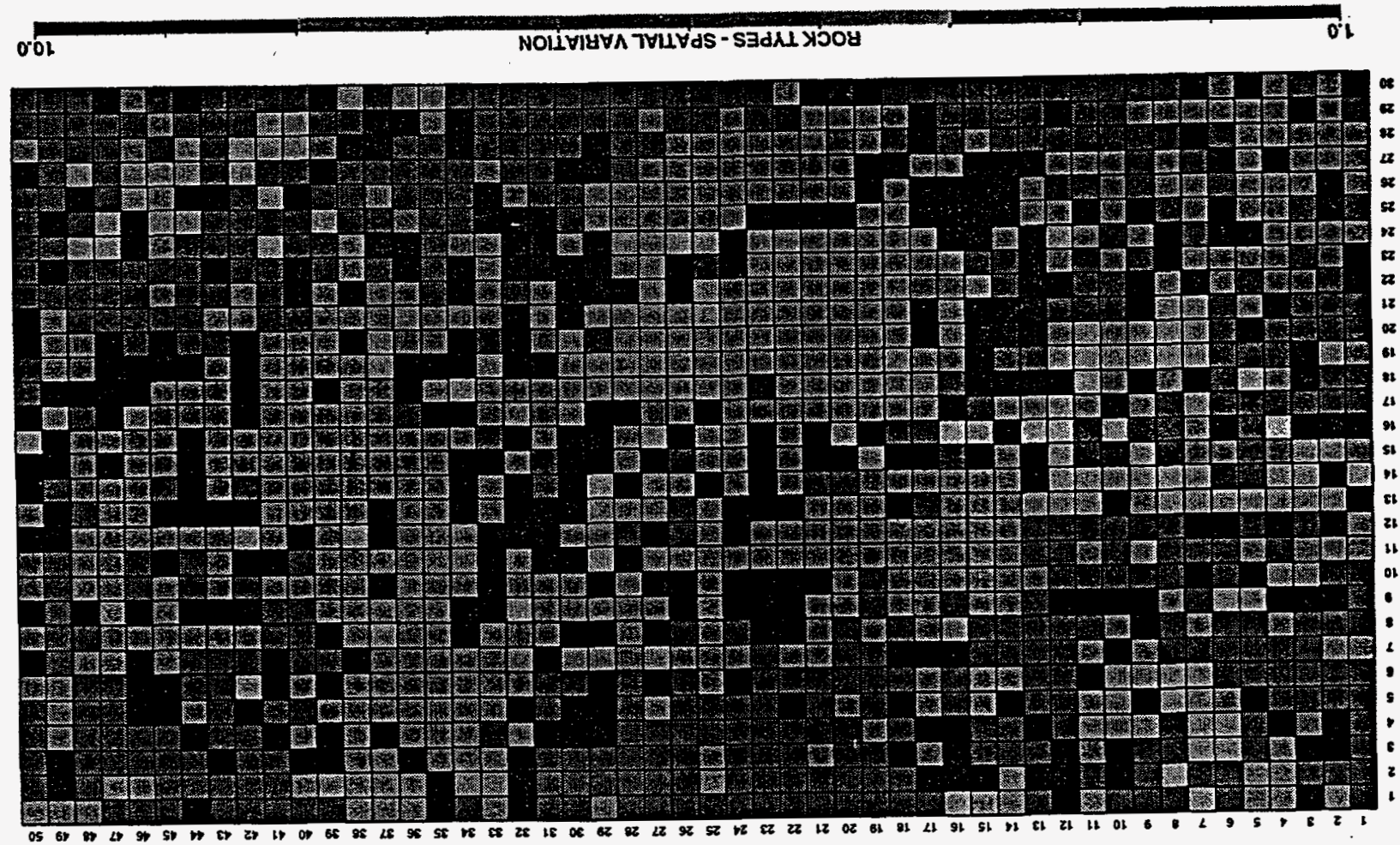

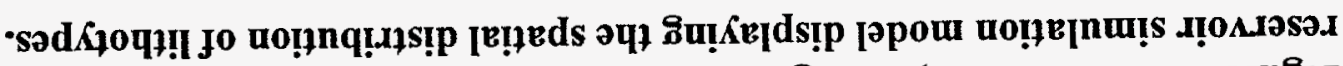

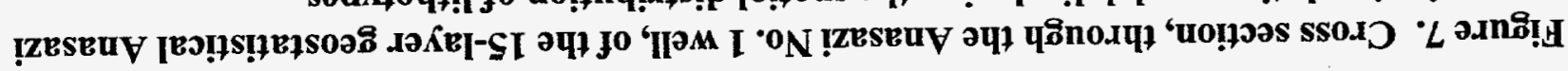

$0 Z=\lambda$ YOJ $\exists N \forall 7 d Z X \perp N O U J$
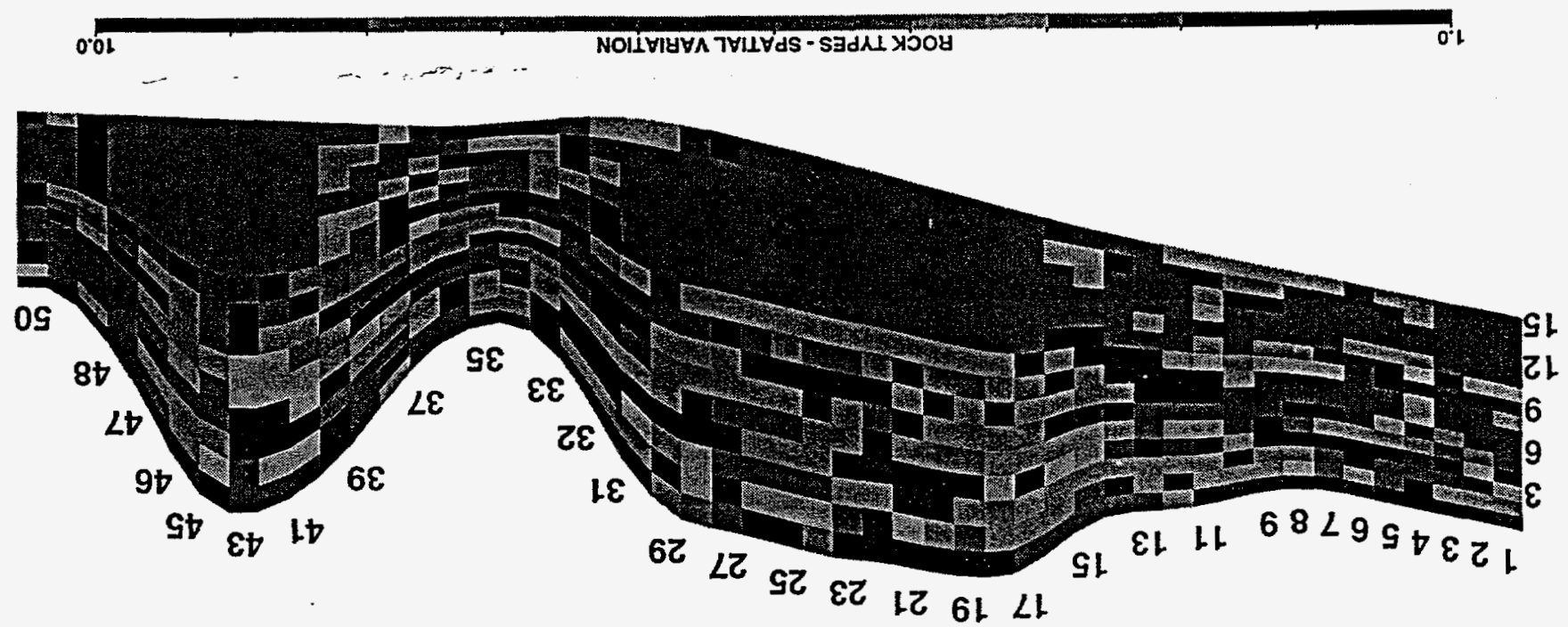
interval [shown as light-to-medium gray] draped across the top of the mound core), some spatial continuity is altered in the rescaling process.

Of the ten equally probably geostatistical realizations of the reservoir model thus generated, one has been selected for conducting the history matching phase of the reservoir simulation. Additional minor adjustments of the original model constraints are being made in response to differences between the simulated reservoir behavior and observed production performance. When this process is completed, additional realizations will be generated to represent the full range of possible configurations of internal architecture and distribution of reservoir properties, consistent with known reservoir production behavior. This final model will be implemented in the predictive phases in the Anasazi reservoir performance simulation studies.

\section{Technology Transfer}

The UGS's home page on the Internet (http://utstdpwww.state.ut.us/ ugs/) includes a page under the heading Economic Geology Program, which describes the UGS/DOE cooperative studies (Paradox basin, Bluebell field, and Ferron Sandstone), contains the latest issue of Petroleum News, and has a link to the U.S. Department of Energy web site. Each UGS/DOE cooperative study also has its own separate page on the UGS web site. The Paradox basin project page (http://utstdpwww.state.ut.us/ ugs/paradox.htm) contains: (1) a project location map, (2) a description of the project, (3) a list of project participants and their postal addresses and phone numbers, (4) each of the project Quarterly Technical Progress reports, (5) a portion of the First Annual Technical Report, (6) a reference list of all publications that are a direct result of the project, and (7) information on the Geology and Resources of the Paradox Basin Symposium and UGSsponsored Class II workshop.

A project overview and poster display was presented to industry representatives at a workshop entitled Improving Production from Shallow Shelf Carbonate (Class 2) Reservoirs sponsored by DOE, BDM-Oklahoma, Inc., and the Center for Energy and Economic Diversification (CEED) in Midland, Tex. on May 15 and 16, 1996. Project material was displayed at the UGS booth during the American Association of Petroleum Geologists (AAPG) annual convention held in San Diego, Calif., May 19-22, 1996. A paper was presented describing the reservoir characteristics of the five project fields. ${ }^{8}$ The UGS also released the May 1996 issue of Petroleum News featuring the Paradox basin project.

\section{References}

1. D. E. Eby, W. G. Groen, and J. F. Johnson, Composition of Seismically Identified Satellite Mounds Surrounding Greater Aneth Field, Southeast Utah [abs.]: Am. Assoc. of Petrol. Geol. Bull. 77(8):1446-1447 (1993).

2. T. C. Chidsey, Jr., D. E. Eby, and D. M. Lorenz, Geological and Reservoir Characterization of Small Shallow-shelf Carbonate Fields, Southern Paradox Basin, Utah, Geology and Resources of the Paradox Basin (A. C. Huffman, Jr., W. R. Lund, and L. H. Godwin, Eds.), 
Utah Geol. Assoc. Pub. 25: 39-56 (1996).

3. D. A. Best, F. M. Wright, III, Rajiv Sagar, and L. J. Weber, 1995, Contribution of Outcrop Data to Improve Understanding of Field Performance - Rock Exposures at Eight Foot Rapids Tied to the Aneth Field, Hydrocarbon Reservoir Characterization - Geologic Framework and Flow Unit Modeling (E. L. Stout and P. M. Harris, Eds.), Soc. of Econ. Paleo. and Min. Short Course 34: 31-50 (1995).

4. L. J. Weber, F. M. Wright, J. F. Sarg, Ed Shaw, L. P. Harman, J. B. Vanderhill, and D. A. Best, Reservoir Delineation and Performance - Application of Sequence Stratigraphy and Integration of Petrophysics and Engineering data, Aneth Field, Southeast Utah, U.S.A., Hydrocarbon Reservoir Characterization - Geologic Framework and Flow Unit Modeling (E. L. Stout and P. M. Harris, Eds.), Soc. of Econ. Paleo. and Min. Short Course 34: 1-29 (1995).

5. J. L. Beall, I. T. Gordon, J. P. Gournay, B. L. Kirkland, and J. V. White, 1996, Analysis of Porosity in Lower Ismay Phylloid Algal Packstone Using High-resolution Computed X-ray Tomography [abs.]: Amer. Assoc. of Petrol. Geol. Annual Convention, Program with Abstracts: A13 (1996).

6. G. M. Grammar, G. P. Eberli, F. S. P. Van Buchem, G. M. Stevenson, and Peter Homewood, Application of High-resolution Sequence Stratigraphy to Evaluate Lateral Variability in Outcrop and Subsurface - Desert Creek and Ismay Intervals, Paradox Basin, Paleozoic Systems of the Rocky Mountain Region (M. W. Longman and M. D. Sonnenfeld, Eds.): Rocky Mtn. Sec., SEPM (Soc. for Sed. Geol.): 235-266 (1996).

7. T. C. Chidsey, Jr., Lisë Brinton, D. E. Eby, and Kris Hartmann, Carbonate-Mound Reservoirs in the Paradox Formation - An Outcrop Analogue Along the San Juan River, Southeastern Utah, Geology and Resources of the Paradox Basin (A. C. Huffman, Jr., W. R. Lund, and L. H. Godwin, Eds.), Utah Geol. Assoc. Pub. 25: 139-156 (1996).

8. T. C. Chidsey, Jr., and D. E. Eby, Geological and Reservoir Characterization of Shallowshelf Carbonate Fields, Southern Paradox Basin, Utah [abs.]: Amer. Assoc. of Petrol. Geol. Annual Convention, Program with Abstracts: A26 (1996). 


\section{Next Quarter Activities}

Activities planned for the next quarter (July 1 through September 30, 1996) include:

1. Prepare a report on the major facies in the field reservoirs.

2. Continue thin section petrography of Anasazi wells in order to: (a) establish a catalog of grain types and depositional facies, (b) develop a display and catalog of major porosity types as seen in thin sections, (c) develop a display of typical porosity types and lithology as a function of log response, and (d) construet a diagenetic history for the reservoir zones.

3. Continue data collection. Well information such as oil, gas, and water analyses; core descriptions; reservoir tops; and other data will be entered into the UGS database for manipulation.

4. Continue work on various reservoir maps for project fields. Complete seismic interpretations at Mule field.

5. Complete Mule area seismic permitting and begin seismic acquisition.

6. Compete evaluation and interpretation of data collected from outcrop reservoir analogues along the San Juan River. Prepare a report describing sequence stratigraphic framework, depositional patterns, and reservoir flow units, barriers, and baffles.

7. Evaluate petrophysical models of the five project fields utilizing geophysical logs and conventional core data on new petrophysical software. Integrate pressure transient work with petrophysical work.

8. Produce table of basic reservoir parameters for each field.

9. Evaluate Runway field potential for $\mathrm{CO}_{2}$ flood simulation in addition to Anasazi field.

10. Generate new geostatistical descriptions of internal architecture and porosity/permeability distribution for reservoir flow simulation modeling. Write up report on geostatistical modeling.

11. Finalize plotting of mechanistic one-dimensional (i.e. slim tube) simulation runs to define the nature of $\mathrm{CO}_{2}$ displacement and compare to ternary phase plots developed from multiple contract runs using phase behavior prediction software.

12. Finalize full field simulation runs for history matching of field production performance.

13. Deliver all lab results (permeability, rock compressibility, $\mathrm{CO}_{2}$ swelling tests, etc.). 
14. Conduct the following technology transfer activities: (a) complete and submit papers on the five project fields for the Utah Geological Association (UGA) Publication 22 entitled Oil and Gas Fields of Utah, second edition, (b) continue planning for the Geology and Resources of the Paradox Basin symposium sponsored by the Bureau of Indian Affairs, UGS, UGA, U.S. Geological Survey, Colorado Geological Survey, Four Corners Geological Society, Fort Lewis College, Ute Mountain Ute Indian Tribe, and DOE. A UGS workshop presenting the results of phase 1 (budget period 1) and a field trip to outcrops and Anasazi field facilities will be part of this symposium, (c) submit papers on the outcrop analogues and reservoir characterization for the Paradox basin symposium guidebook entitled Geology and Resources of the Paradox Basin, (d) make technical presentations at the Rocky Mountain Section meeting of the American Association of Petroleum Geologists (AAPG) in Billings, Mont., and (e) submit abstract to the AAPG for presenting project-reservoir modeling and simulation results at a poster session entitled Results of Joint DOE/Industry Programs during the AAPG Annual Convention in Dallas, Tex, April 6-9, 1997. 